
РОЛЬ ПІДРУЧНИКА З ІНОЗЕМНОї МОВИ
У ФОРМУВАННІ ОСОБИСТОСТІ УЧНЯ

\title{
THE ROLE OF THE FOREIGN LANGUAGE TEXTBOOK IN SHAPING THE STUDENT'S PERSONALITY
}

\begin{abstract}
У статmі розглядається роль підручника 3 іноземної мови у орормуванні особистості учня. Автор наголошує на тому, що завдання підручника з іноземної мови не зводиться до викладу теорії та завдань для їі практики. Він виконує інорормаційну, організаційну, мотиваційну, контролюючу, розвиваючу та виховну функції. Це пов'язано з тим, що в підручнику розміщено і різнорівневі різнопланові завдання, які допомагають розвивати увагу, мислення, пам'ять, проявити креативність та індивідуальність учня в прочесі навчання. Ілюстративний матеріал допомагає наочно ознайомитись із концептами, що характеризують країну, мова якої вивчається, мотивують школярів на пізнавальну діяльність. Побудова підручника на основі ситуативного підходу дає змогу школярам фрормувати стереотипи поведінки в тих чи інших життєвих ситуаціях, усвідомлювати сорери використання отриманих знань у подальшому житті. Також у підручниках з іноземної мови є соціокультурне навантаження: учень знайомиться із традиціями, особливостями менталітету, національною їжею, прави лами етикету, фрормує толерантне ставлення до народу, особливостей менталітету, цінностей і культури країни, мову якої вивчає. Поряд з іншомовною культурою учні розширюють діапазон знань про власну державу, знаходять спільні та відмінні риси між культурами, замислюються над власними традиціями, виховують патріотизм і любов до країни, в якій проживають, усвідомлюють їі унікальність і иілісність. Загалом, за словами автора, зміст підручника пробуджує інтерес до предмета, сприяє стійкому фрормуванню пізнавальних рис, розвиває вміння учнів самостійно мислити, працювати 3 книгою, аналізувати, розвивати бажання поповнювати свої знання, використовувати їх у своєму житті, розширювати предметні компетенції незалежно від форм і способів організації навчального процесу.
\end{abstract}

Ключові слова: підручник з іноземної мови, іноземна мова, формування особистост учня, фрункції підручника, шкільна освіта.

The article deals with the role of the foreign language textbook in the student's personality formation. The author emphasizes that the main task of a foreign language textbook is not only to represent theory and tasks for its practice. It performs informational, organizational, motivational, controlling, educational and edifying functions. This is due to the fact that the textbook contains a variety of multifaceted tasks that help develop attention, thinking, memory, creativity and identity. Illustrative material helps in understanding the concepts that characterize the country of the language being taught, motivate students to cognitive activity. Creation a textbook based on a situational approach allows schoolchildren to form stereotypes of behavior in certain life situations, to be able to use the acquired knowledge of a foreign language in appropriate spheres of life. Also there is a sociocultural component in foreign language textbooks: the student gets acquainted with the traditions, peculiarities of the mentality, national food, rules of etiquette, forms a tolerant attitude to the people, values and culture of the country and people whose language he is learning. Along with foreign culture, students expand the range of knowledge about their own state, find common and distinct traits between cultures, cultivate patriotism and love for the country in which they live. In general, according to the author's opinion, the content of the textbook arouses interest to the subject, promotes the sustainable formation of cognitive qualities, develops the ability to think independently, work with a book, and develop a desire to supplement their knowledge, to expand subject competences, regardless of the forms and ways of organizing the educational process.

Key words: foreign language textbook, foreign language, student personality formation, textbook functions, school education.
Постановка проблеми в загальному вигляді. Згідно з чинним державним стандартом базової і повної загальної середньої освіти навчальний процес спрямовується не на отримання окремих знань і вмінь, а на розвиток ключових і предметних компетентностей, які стануть основою для фрормування успішної всебічно розвиненої особистості. Однією із ключових компетенцій є здатність спілкуватись іноземною мовою. Це пов'язано з тим, що в умовах сучасного суспільства успішна людина повинна вміти діяти в будь-якій ситуації, володіти різними мовами для побудови нових соціальних зв'язків і кар'єрного зростання. Отже, неабияку увагу слід приділити процесу оволодіння школярами іноземною мовою. Згідно із загальноприйнятою шкільною програмою вивчення іноземної мови в Україні здійснюється 3 опорою на підручник, який відповідає всім методичним вимогам і враховує вікові особливості учнів. Саме він виступає багатофрункціональним джерелом знань, засобом їхнього усвідомленого засвоєння на різних етапах навчання, інструментом для самостійної та аудиторної роботи. Однак підручник з іноземної мови повинен не лише надавати теоретичний матеріал, але і сприяти формуванню особистості учня.

Аналіз останніх досліджень і публікацій. Як свідчить аналіз теоретичних джерел, чимало дослідників і методистів вивчало роль підручника в системі освіти (М. Бурда, Д. Зуєв, О. Савченко, Я. Кодлюк), зокрема, під час вивчення іноземної мови (С. Ніколаєва, В. Чорний, В. Редько). Роботи цих дослідників усебічно описують значення підручника в навчальному процесі, його пізнавальну значимість, завдання, що пропонуються у ньому, 
однак не досить розкривають роль підручника з іноземної мови не як засобу отримання знань, а чинника фрормування особистості учня.

Мета статті - розглянути основні можливості підручника у формуванні особистості учня.

Виклад основного матеріалу. Сучасні підручники містять не лише суто навчальну інфрормацію, але й різноманітні вправи для покращення інтелектуальної сорери дитини. Обґрунтування ролі шкільного підручника у орормуванні особистості знаходимо в дослідженнях Н.М. Бібік, яка наголошує, що мета сучасної шкільної освіти «... постає не як сумарне вираження знань і вмінь із предметів навчального плану, а як інтегрований показник усіх етапів становлення особистості, що охоплює не лише результати навчально-виховного процесу, а й життєвий і навчальний досвід учня, умови й характеристики процесу навчання та виховання» $[1$, c. 49]. Тобто поряд із традиційним знаннями 3 іноземної мови підручник як базовий складник уроку повинен відображувати реалії життя, місце людини у світі, важливість дотримання загальноприйнятих соціальних норм та установок, сприяти формуванню загальнолюдських цінностей.

Перш за все, беручи до рук підручник з іноземної мови, дитина звертає увагу на його зовнішній вигляд. Це вже фрормує перше враження від книги та предмета загалом. Наприклад, якщо підручник має середній розмір, надрукований на якісному папері, містить яскраві доречні ілюстрації, має блокову структуру викладу матеріалу, він одразу привертає увагу школяра та мотивує його не лише переглянути, візуально сприйняти книгу, але й зазирнути у її зміст. Тобто ми говоримо про те, що найпершою фрункцією, котру виконує підручник з іноземної мови, є розвиток мотиваційної сфери та установки навчатись. Детальніше зупинимось на вимогах до зовнішнього вигляду підручника з іноземної мови, який сприятиме розвитку мотиваційної сфрери учнів. Оскільки підручник виступає засобом наочності, то неабияку увагу слід приділяти ілюстраціям і способу подання інформації. Доцільно використовувати яскраві доречні ілюстрації, за змістом наближені до реального життя. При цьому малюнки не повинні займати більше $20 \%$ простору на одному розвороті книги, оскільки це відволікатиме дитину від навчального процесу, перетворить урок у перегляд ілюстрацій. Велике значення має і оформлення текстової частини: доцільно використовувати в підручниках чорний шрифт, оскільки він добре сприймається зором, легко читається та не спричиняє зорового перенавантаження. Щодо викладу матеріалу, то найбільшу цікавість серед учнів викликають ті підручники, у яких простежується строго визначена структура та $€$ чітка послідовність завдань. Дуже зручним для дитини є розміщення теми одного уроку на одній сторінці підручника чи на одному розвороті, коли школяр має можливість послідовно виконувати всі завдання, бачить перед собою чітко визначену теорію, завдання для ії тренування, словничок нових термінів, домашнє завдання та додаткове творче завдання [7, с. 159]. Високий мотиваційний потенціал має розміщення в кінці кожного розділу підручника художнього тексту для читання, що відповідає віку і запитам школярів, та матеріалів уроку-подорожі для закріплення та систематизації отриманих знань. Підвищенню зацікавленості учнів сприяє і використання знайомих їм мультиплікаційних та ігрових образів (популярні сьогодні «фіксики», «смішарики»), персонажів із фрільмів і серіалів, оскільки серед незнайомого «чужого» матеріалу дитина натрапляє на щось «своє», досвід роботи з чим у неї вже був.

Ще одним складником підручника 3 іноземної мови, який сприяє розвитку особистісних рис учня, $є$ наявність різних рівнів складності завдань. На перший погляд це традиційний методичний прийом, коли діти можуть виконувати завдання відповідно до своїх знань, однак його роль дещо недооцінена. Насамперед наявність різнорівневих завдань дає дитині змогу самій оцінити свої знання, тобто дає можливість навчитись критично оцінювати власні можливості і виконувати лише ті завдання, які їй до снаги. Крім того, школярі з нижчим рівнем знань прагнуть «дотягнутись» до своїх більш успішних товаришів, а тому знову випливає момент мотивації. Також поетапне виконання завдань різного рівня навчає дитину іти від простого до складного [8, с. 136].

Надважливу роль у фрормуванні особистості учня відіграє підбір тем підручника та завдань до них. Перш за все, важливим фрактором $€$ відповідність між темами підручника та навчальною програмою. Звичайно, усі підручники відповідають базовій навчальній програмі, оскільки проходять спеціальний конкурс, однак календарне планування вчителя та теми підручника часто відрізняються. Це має велике значення, бо під час повідомлення теми уроку учень, розгортаючи книгу, повинен чітко бачити, що пропонують йому на цьому уроці, з яким матеріалом він може ознайомитись. Однак акцент слід зробити саме на змісті тем, які пропонуються дитині на вивчення підручником, і. відповідно, на завданнях, що до них додаються. Щодо змісту тем і завдань, то в сучасних підручниках 3 іноземної мови значна увага приділяється ситуативності, а саме побудові таких завдань, з якими б дитина могла стикнутися в реальному житті, наприклад діалог із жителем Лондона, покупки в супермаркеті, подорож Англією, екскурсія по картинній галереї, листування з іноземним другом і багато іншого. Ситуативні завдання дають змогу школярам не просто опанувати іноземну мову, але і навчитись використовувати її у звичайних життєвих ситуаціях, швидко 
реагувати на запити співрозмовника, вміти підтримати бесіду, давати точні лаконічні відповіді тощо [3, с. 142]. Також у підручнику іноземної мови ми спостерігаємо чимало завдань, спрямованих на розвиток мислення, уваги та пам'яті. Наприклад, мислення розвивають завдання на закінчення творів чи написання творів-роздумів, з'єднання двох частин речень, встановлення відповідності, кросворди, ребуси тощо. Завдання на заповнення пропусків у реченні після прочитання тексту чи прослуховування аудіо, складання слів із запропонованих літер, відтворення скоромовок розвивають пам'ять. Покращенню уваги сприяє аудіювання, завдання на підкреслення слів із певної теми, певної граматичної фрорми тощо [6, с. 202] Варто додати, що підручник можна залучати не лише під час класної роботи, але й під час самостійної підготовки учня. В цьому випадку саме шкільна книга стає путівником і товаришем дитини у світі нових знань. Так дитина навчається працювати самостійно, знаходити потрібні відповіді, використовуючи всі можливості книги. Тексти для читання, подані в підручнику, розвивають культуру читання, вміння працювати з текстовим матеріалом, активізують пізнавальну діяльність школярів, прививають любов до книги, знайомлять із творчістю зарубіжних письменників і манерою іншомовних художніх текстів. У підручниках іноземної мови також вміщено автентичні уривки з газетних і журнальних текстів, текстів науково-популярного і публіцистичного стилів, що дає учням змогу практикуватися у розумінні іноземної преси, розуміти їі основний зміст, виділяти основну думку, уміти переглянути значний за обсягом текст для пошуку необхідної інфрормації, здобувати інорормацію 3 оголошень, проспектів, меню, розкладів, брошур, коротких офріційних документів [2].

Не можна залишити поза увагою творчі завдання. Вивчення іноземної мови в школі зазвичай зводиться до ознайомлення 3 теоретичним матеріалом та його практикою, при цьому школярі не мають можливості проявити свою індивідуальність і креативність. У підручниках після завершення теми часто пропонується творче завдання, спрямоване на створення відео, проєктів, презентацій, перегляд іншомовних кінофільмів і багато іншого. Такі завдання дають можливість учням спробувати себе в різних ролях (журналіста, фоотографра, митця, режисера), застосувати вміння 3 інших галузей знань (володіння комп'ютером, спів, танці, спортивні досягнення, художнє бачення), відтворити власне бачення світу, виразити свою особистість. Крім того, у процесі створення чогось якісно нового дитина вчиться спілкуватись з однолітками, домовлятись, знаходити компроміси, виражати власну думку та відстоювати ії, приймати рішення, знаходити різноманітні способи реалізації поставлених завдань [4, с. 281]. Отже, здавалось би традиційні завдання можуть виконувати низку фрункцій, необхідних для формування успішної особистості. Оскільки оволодіння іноземної мовою передбачає і письмові навички, то в підручниках розміщено чимало письмових завдань. Саме вони дають змогу дитині навчитись робити нотатки, складати план, написати лист, повідомлення, автобіографію, писати твори в межах визначених сорер спілкування, висловлюючи власне ставлення до проблем, які порушуються, вміти грамотно та послідовно викласти власні думки на папері.

Окрім освітньої та розвиваючої функцій, підручник також реалізує виховну мету навчання. Програма вивчення англійської мови передбачає знайомство школярів з автентичною культурою країни, мова якої вивчається. Саме тексти, розміщені в підручнику, розкривають дитині зміст традицій іншої країни, особливості менталітету, вподобання у їжі, національні риси та багато іншого. Варто зазначити, що саме в підручнику учень має змогу і роздивитись ілюстрації іншомовних реалій (тарт Бейквел, кеджері, бастард тарт, вбрання на Геловін, особливості прикрашання різдвяних будинків) і прочитати про них. Так у дитини розвивається вміння виконувати комунікативні фрункції, застосовуючи мовленнєві зразки відповідно до лінгвокраїнознавчих і соціокультурних вимог іншої держави, застосовувати основні правила етикету, виховуються повага та толерантне ставлення до народу, цінностей і культури країни, мову якої вона вивчає, розширюється світогляд [5, с. 174].

Зазначимо, що важливо не лише викликати інтерес до вивчення іноземної культури, але й розширювати знання про власну. Чимало тем у програмі вивчення іноземної мови присвячені і Україні, а саме - розвитку вміння учнів презентувати власну країну на світовій арені. Наприклад, школярі вивчають іншомовне позначення української символіки, вчаться розповідати про звичаї та обряди, рідне місто, мальовничі куточки України, видатних постатей тощо. Вони практикуються у порівнянні власної та іноземної культури, знаходять спільні та відмінні риси, виховують патріотизм і любов до країни, в якій проживають, усвідомлюють її унікальність.

Наостанок варто згадати і про звичайне вміння працювати з книгою. Сьогодні, в епоху сучасних технологій, діти змалечку звикають до електронних носіїв: вони грають в ігри, дивляться мультфрільми, навіть навчаються, користуючись спеціальним розвиваючими програмами. Наприклад, вже у віці 6-7 років, коли дитина йде до першого класу, виявляється, що вона настільки звикла до електронних носіїв інфрормації, що вже не вміє працювати 3 книгою і вважає ії нецікавою. Це негативно позначається на подальшому навчанні і загальному розвиткові дитини. Вченими дове- 
дено, що люди, які багато читають, мають глибше мислення, неабиякий творчий потенціал та уяву, великий словниковий запас, вміють чітко висловлювати власну думку, більш інтелектуально розвинені. Вони пояснюють це тим, що, читаючи, людина постійно розшифрровує буквений код, уявляє образи, домальовує в уяві картини, мислить та аналізує, тобто ії мозок не пасивно обробляє готову інфрормацію, а активно працює над створення цілісної картини. Водночас користування комп'ютером і ґаджетами передбачає отримання вже готових образів і не сприяє розвитку когнітивних здібностей людини. Отже, робота з підручником на уроках іноземної мови стимулює образне мислення учнів, розвиток інтелекту та вміння працювати з друкованим матеріалом.

Підсумувавши вищесказане, можна зробити висновок, що підручник з іноземної мови виконує такі фрункції:

- інформаційну (містить теоретичний матеріал, що підлягає подальшому вивченню);

- організаційну (побудований відповідно до навчальної програми, має чітку структуру, що узгоджується з основними етапами уроку);

- мотиваційну (різними засобами впливу підвищує зацікавленість учня іноземною мовою, демонструє ситуації, в яких він може використати отримані знання);

- контролюючу (окремі завдання можуть використовуватись для контролю та перевірки рівня отриманих знань як учителем, так і учнем);

- розвивально-виховну (сприяє розвитку інтелектуальних здібностей, моральних якостей, толерантності до іншомовної культури, патріотизму);

- діяльнісну (наштовхує учнів на виконання продуктивної діяльності, а саме вирішення різнорівневих різнопланових завдань, написання творів, читання автентичних текстів).

Висновки. Отже, використання підручника на уроках іноземної мови сприяє збагаченню активного словникового запасу учнів, удосконалення базових лексичних, граматичних, стилістичних, правописних умінь і навичок, активізації пізна- вальної діяльності, тренуванню у використанні іноземної мови в різних ситуаціях і сорерах життєдіяльності, розвиває мовні, інтелектуальні та пізнавальні здібності, сприяє засвоєнню національних і загальнолюдських цінностей, усвідомленню учнями особливостей культури народів, мови яких вивчаються, власної національної культури, забезпечує розкриття потенціалу та естетичної цінності творів іноземної літератури, срормування світогляду учнів, їхньої національної свідомості, моралі та громадянської позиції. Учень у підручнику має знайти матеріал до кожної теми для самостійного опрацювання, поглиблення знань і розвитку вмінь.

\section{БІБЛІОГРАФІЧНИЙ СПИСОК:}

1. Бібік Н.М. Врахування пізнавальних інтересів учнів у підручникотворенні. Підручник XXI століття. 2003. № 1-4. С. 48-52.

2. Державний стандарт базової і повної загальної середньої освіти. URL: http://www.mon.gov.ua/images/ files/doshkilna-cerednya/serednya/derzh-standart/post_ derzh_stan.doc.

3. Загальноєвропейські Рекомендації 3 мовної освіти: вивчення, викладання, оцінювання / наук. ред. укр. вид. докт. пед. наук, проф. С.Ю. Ніколаєва. Київ : Ленвіт, 2003. 273 с.

4. Кремень В.Г. Освіта і наука в Україні - інноваційні аспекти. Стратегія. Реалізація. Результати. Київ : Грамота, 2005. 448 с.

5. Лінгводидактичні засади навчання іноземної мови учнів старших класів загальноосвітніх навчальних закладів : навч.-метод. посібник / В.Г. Редько, Т.К. Полонська, Н.П. Басай, О.С. Пасічник та ін. ; за наук. ред. В.Г. Редька. Київ : Педагогічна думка, 2013. $360 \mathrm{c}$

6. Малафіїк І.В. Дидактика : навч. посіб. Київ : Кондор, 2006. 398 с.

7. Методика навчання іноземних мов у загальноосвітніх навчальних закладах : підруч. для студ. вищ. навч. закл. / Л.С. Панова, І.Ф. Андрійко, С.В. Тезікова та ін. Київ : ВЦ «Академія», 2010. 328 с.

8. Редько В.Г. Засоби фрормування комунікативної компетентності у змісті шкільних підручників з іноземних мов. Теорія і практика : монографрія. Київ : Генеза, 2012. 224 с. 